\title{
Article \\ Measuring Synergies of Banks' Cross-Border Mergers by Real Options: Case Study of Luminor Group AB
}

\author{
Andrejs Čirjevskis
}

Citation: Čirjevskis, Andrejs. 2021.

Measuring Synergies of Banks'

Cross-Border Mergers by Real

Options: Case Study of Luminor

Group AB. Journal of Risk and Financial

Management 14: 403. https://

doi.org/10.3390/jrfm14090403

Academic Editor: Alin

Marius Andries

Received: 23 July 2021

Accepted: 23 August 2021

Published: 26 August 2021

Publisher's Note: MDPI stays neutral with regard to jurisdictional claims in published maps and institutional affiliations.

Business Department, RISEBA University of Applied Sciences in Business, Arts and Technology, Meza Street 3 , LV 1048 Riga, Latvia; andrejs.cirjevskis@riseba.lv

\begin{abstract}
Applying the real options valuation to measure merger and acquisition (M\&A) synergy is highly debatable, with questions arising from the usefulness of this approach in real-world settings. Understanding the full benefits (and possible limits) of real options applications to measure synergy in cross-border merger activities remains a challenge. The main objective of the paper is to explore multiple types of synergies in the recent, highly strategic cross-border merger-the Luminor Group AB deal-and to value those synergies with the real options application. The research found that the sum of values of different types of synergies in M\&A deals as the market value added provided by this deal could be valued with real options applications. A real options application may serve as a decision-making tool and at the same time be a useful valuation method of M\&A deal synergies. The implications of this paper are twofold. First, the research contributes to corporate financing by providing relevant synergy measurement models in M\&A deals. Second, the paper contributes to "grand challenges" research topics of international businesses by illustrating how a group of multinational banks solved the problem of income inequality across countries, and balanced inequality within their networks through a cross-border merger.
\end{abstract}

Keywords: cross-border merger; synergies; real options

\section{Introduction: The Aim, Motivation, and Contributions}

This paper aims to explore multiple types of synergies in the recent highly strategic cross-border merger-the Luminor Group AB (Sweden) deal-and to value five types of synergies (Feldman and Hernandez 2021) with the real options application. The motivation of this research is as follows. Having explored the synergistic combination of an acquirer and a target, scholars unpacked novel synergy sources and typical synergy management pitfalls of mergers and acquisitions (M\&A) (Fiorentino and Garzella 2015; Sakhartov and Reuer 2021; Feldman and Hernandez 2021), but they did not bind synergism with the real options theory. Several authors employed the real options valuation to measure the synergy effect of M\&A deals (Yu and Xu 2011; Loukianova et al. 2017; Barbopoulos et al. 2019), but they did not specify the type, timing, and duration of synergies in merger and acquisition (M\&A) processes.

The author integrates the latest research findings on the synergy management process with the real options valuation approach and synthesizes what was previously explored, justifying the paper's novelty. Moreover, Chi et al. (2019) argue that the real options theory, in the international business context, could contribute to real options-based research to three core international business (IB) issues: timing and scale of market entry, entry mode, and governance form, and the role of multinational networks. In this vein, the cross-border merger of Luminor $A B$ is a suitable case study to synthesize the insights of recent studies on synergies and to discuss the application of the real options theory, to better understand feasible solutions to the above-mentioned IB challenges.

Having done the case study research on the establishment of Luminor Group AB (Sweden) based on the Baltic operations of Nordea (Finland) and DNB (Norway) in Lithuania, 
Latvia, and Estonia in August 2017, the paper contributes to Chi et al.'s (2019) scientific requests, discussed in the conclusion section.

Bringing together the best approaches from corporate finance, on real options valuation and strategic management theories on synergies, this paper also contributes to the "grand challenges" (Buckley et al. 2017) of international business by evidencing how the above-mentioned international banks have balanced inequality within their international networks and appropriated synergism of their cross-border merger strategies. Thus, the paper demonstrates originality by providing interdisciplinary research that contributes to three different disciplines: corporate finance, strategic management, and international business in a cohesive whole.

The remainder of the paper is organized as follows. In the first section, the paper explores the typical synergy management pitfalls: misunderstanding types of synergies of M\&A deals and inappropriate synergy valuation models in M\&A deals. Then, the paper explores real options arguments in relation to M\&A deals, discusses real option value variables, and considers how to apply real options, measuring the sum of different types of synergies in M\&A deals. The section is devoted, respectively, toward developing several propositions that have been empirically justified by a cross-border merger (in the Luminor $\mathrm{AB}$ case study). Having justified propositions in the next section, the paper contributes to interdisciplinary research by bridging strategic management, the real options theory, and international business discipline in a holistic synthesized view through case study research of the Luminor Group AB, which was established in 2017 and sold to the Blackstone Group (USA) in 2019. At the end of the paper, the author discusses theoretical and empirical findings, limitations, and future work.

\section{Theoretical Background}

\subsection{Exploring Types of Synergies and Valuation of Synergies in MEA Deals}

According to Sakhartov and Reuer (2021), "synergy is the enhancement in performance of a multi-business firm over the performance of its constituent businesses if they were operated as separate, single-business firms" (Sakhartov and Reuer 2021, p. 3). Similarly, Feldman, and Feldman and Hernandez (2021) summarized that synergy is "a combination of two firm's assets that are more valuable together than they are separate" Feldman and Hernandez (2021, p. 2). Hoberg and Phillips (2010) provided direct evidence on asset complementarities as a source of synergy and gains of a merger. The authors found that asset complementarities of business partners provide market value added. Their hypothesis was supported by the positive and significant "target plus acquirer" similarity coefficient (Hoberg and Phillips 2010). Rhodes-Kropf and Robinson (2008) also consider asset complementarities as a motive for mergers, and synergies as a gain of a merger.

Goold and Campbell (1998) argued that most business synergies take one of six forms: leveraging core competencies and sharing best practices; gain economy of scale and avoid duplication, gain greater leverage over suppliers, coordinate and sustain competitive advantage; accelerate the speed of product development, and establish a new unit by combining know-how form different units. Puranam and Vanneste (2016) provided four types of synergies based on the resource-based view (RBV) theory: combination, consolidation, customization, and connection on two different dimensions: "the resource modification required post-acquisition, and the similarity between those resources" (Feldman and Hernandez 2021, p. 8). Depending on the similarity of the resources and the need to modify them in search of a new customer value proposition, there are four types of M\&A synergy. If there is a low modification of resources, the synergy comes from the combination of similar resources or the connection of dissimilar resources. If there is a high modification of resources needed, the synergy derives from the consolidation of similar resources or the customization of dissimilar resources.

Feldman and Hernandez (2021) found that research since the 1980s demonstrated that market value added arises through strategic cooperative interactions; however, "these theoretical advances have not systematically made their way into the M\&A literature" 
(Feldman and Hernandez 2021, p. 6). Furthermore, the McKinsey \& Company found that only $20 \%$ of acquirers publicly announced and disclosed the synergies they intended to capture (Agrawal et al. 2017). Hoberg and Phillips (2010) also found that the literature was not able to identify whether asset complementarities, allowing firms to introduce new products are responsible for synergetic gains. Moreover, external cooperative relationships were mentioned as sources of value in fewer than $5 \%$ of M\&A studies reviewed by Feldman and Hernandez (2021, p. 5)

Fiorentino and Garzella (2015) argued that there are several reasons why only a few M\&As specified synergies in their deals (Agrawal et al. 2017). The authors provided typical synergy management pitfalls of M\&As given in the form of five questions, and mentioned a lack of useful synergy measurement models. According to Fiorentino and Garzella (2015), there are some synergy management pitfalls in mergers and acquisitions, specifically, the problems in the assessment of synergy value and in negotiating the deal price (when?); insufficient clarity around definitions and notions of synergy "potential, realized, effective, achieved", and so on (where?); inappropriate integration processes that lead to a synergy inferior to what was expected (why?); poor management at the due-diligence stage, and the under assessment of integration costs (what?); and the lack of actions and tools to overcome hidden dangers in synergy management (how?) (Fiorentino and Garzella 2015). In this vein, the typical synergy management pitfalls can be clustered into two major groups: the misunderstanding of types of synergies in M\&A deals and inappropriate synergy valuation models in M\&A deals.

Recently, Feldman and Hernandez (2021) contributed toward solving the first synergy management pitfall concerning the types of synergies. Having used not only RBV/capability theories, but four distinct theories of economic rent; industrial organization (IO) economics, the relational and contracting views, social networks theory, and stakeholder and institutional theory-Feldman and Hernandez (2021) classified three new types of collaborative synergy strategies (relational, network, and non-market), and justified two well-known types (internal and market power) that jointly lower costs and enhance revenue, also known as operational.

Because the value in mergers and acquisitions (M\&A) derives from the synergistic combination of an acquirer and a target, Feldman, and Feldman and Hernandez (2021) uncovered three novel synergy sources (relational, network, and non-market) arising from collaborative strategy-induced changes in external cooperative environments of firms, and classified two other well-known synergies (internal), also known as operational and market power (Feldman and Hernandez 2021). The authors considered the type of co-synergy and dis-synergy through the lens of the interaction when merging firms complement each other or substitute for one other. The similarity of resources and capabilities, and the need to dynamically modify them within the post-acquisition process, also provide different types of synergies. Thereby, the added market value created by M\&A can be valued as the sum of different types of synergies (Feldman and Hernandez 2021).

In turn, the second synergy management pitfall is inappropriate synergy valuation models. Fiorentino and Garzella (2015) argue that, "to first analyze and later realize these aims, firms need useful synergy measurement models" (p. 1481). Most (prior) scholarly research on synergies focused on operational sources as cost, revenue, and abnormal return, and financial sources of synergy as the cost of capital, free cash flow, and debt capacity. According to Fiorentino and Garzella (2015), the value of potential M\&A synergy is the present value of the expected synergy flows derived from a deal, discounted back at a rate that reflects the riskiness of those flows (Fiorentino and Garzella 2015). Moreover, Ficery et al. (2007), argue that "synergies are the present value of the net additional cash flow that is generated by a combination of two companies that could not have been generated by either company on its own" (Ficery et al. 2007, p. 35).

According to Puranam and Vanneste (2016), discounted free cash flow (DFCF) is the primary means for synergy valuation philosophy whereas enterprise value (EV)-based multiples could be used for quick target market valuation for preliminary bargaining. 
Thereby, discounted free-cash-flow analysis (DFCF) estimates expected future earnings discounted to their present value, assuming the firms would follow a predetermined plan despite the development of events (Čirjevskis 2021a, p. 3). However, DFCF and the multiples valuation approach experience the problem, and measure managerial flexibility in terms of the ability to modify the resource bases, and are unlikely to grasp the market value added of this process due to the static nature of the DFCF and multiples methods. Sensitivity analysis of NPV of the acquisition, based on the different meanings of the weighted average cost of capital (WACC), the terminal value (TV), and DFCF constant growth rate $(\mathrm{g})$ can add dynamic to the synergy valuation in M\&As, but cannot predict the influences of such post-merger types of synergies as relational, network, and non-market synergies.

While ultimately, all profits show up as revenue gains or cost reductions, Feldman and Hernandez (2021) "encourage M\&A scholars and practitioners to broaden the concept and measurement of the total value of an acquisition" (p. 31). "We hope that ... research will move beyond the basic issue of measuring and assigning gains and losses to tackle the more fundamental question of how mergers actually create or destroy value" (Andrade et al. 2001; Feldman and Hernandez 2021, p. 5). Feldman and Hernandez (2021) are convinced that "the net present value of future cash flows is driven by the size, timing, and uncertainty of those cash flows that it is consistent with a key idea from the finance and real options literatures" (p. 14).

In this vein, the real options application helps one to estimate synergy, in terms of market value added, but not only in terms of cost-saving and/or revenues rising (Čirjevskis 2020). The valuation of M\&A synergies by real options can give practitioners a clearer strategic observation of the synergism of the M\&A deal (Čirjevskis 2020). Thus, the total market value added created by the M\&A deal can be considered as the sum of different types of synergies provided by Feldman and Hernandez (2021) and valued by the real options application.

Therefore,

Proposition 1. The sum of values of different types of synergies in MEA deals is the market value added provided by the deal that can be valued with real options application.

To demonstrate how the real options theory can be employed to value M\&A synergies, the paper further discusses real options valuation methods and their appropriateness for the synergy valuation, and develops new propositions.

\subsection{Exploring Real Options Arguments Concerning MEA Deals}

As noted by Brandão et al. (2005), real options in the broadest sense can be defined as projects that have option-like characteristics; that is, a value of the project is contingent on developments taking place over its duration. However, for any real option to have some value, company management must be both willing and able to exercise (or realize) it, if conditions are appropriate. To achieve this, management must learn to respond to new information. Learning will result in the ability to adjust the project and make optimal decisions over its economic life. This capability is commonly referred to as (managerial) flexibility or "contingency" (Mun 2003, p. 285; Li et al. 2007) or dynamic managerial capabilities (Helfat and Martin 2014).

Not only managers must possess flexibility, but there also must be at least a theoretical possibility that this flexibility could be implemented. This possibility generally stems from the uncertainty associated with the project (Bailey et al. 2003; Adner and Levinthal 2004). In the context of real options, uncertainty is a somewhat generic term, but in essence, refers to the fact that the future value of a particular variable is unclear (Copeland and Keenan 1998a; Triantis and Borison 2001). Most commonly, uncertainty pertains to possible fluctuations in the value of an underlying asset, or the cash flow stream generated by the investment (Luehrman 1998a; Mun 2002, p. 147; Damodaran 2005). 
Therefore, the value of a real option, though rather counter-intuitively, is higher when the uncertainty associated with the undertaking is high (Mauboussin 1999). Only when management can respond, and there is high uncertainty regarding a project, does flexibility have a significant value (Copeland and Keenan 1998b; Mun 2002, p. 82). Additionally, instead of being considered a pure number-crunching exercise, real options are enduringly proclaimed as the means for strategic decision-making, both being a learning tool and a sort of investment "roadmap" at the same time. The real options theory thus provides an effective foundation to deal with decision-making under uncertainty (Luehrman 1998a; Brach 2003, pp. 1-13; Nembhard and Aktan 2009, pp. 7-11).

The purpose of the real options theory in general is to attach a monetary value to managerial flexibility and, particularly, to measure dynamic capabilities-based synergy (Čirjevskis 2021b). Real options logic has been applied in a wide variety of industry and strategic settings, such as application in renewable energy investments (Kozlova 2017), carbon capture and storage (Agaton 2021), infrastructure projects (Martinsa et al. 2013), financial sector (Dunis and Klein 2005), real estate projects (Čirjevskis 2021a). Thus, there is evidence of the usefulness of the real options valuation that helps to determine a project's value-maximizing decisions over its duration (Mun 2002, pp. 173-83; Damodaran 2006; Tong and Reuer 2007).

The real options approach is much suitable to value M\&A synergies in dynamic than the traditional static valuation method (e.g., discounted free cash flows) due to important characteristics of real options, such as the ability to cope with economic uncertainty and to measure managerial flexibility. Hence, there is good reason to apply a real options valuation to M\&A deals to measure a sum of different types of synergies. There are three types of options associated with M\&A deals-expansion or growth option (invest), abandon option (reject), and deferred option (postpone). The growth option and deferred option are valued as a call option while the abandon option is valued as a put option. Decision tree analysis can also be useful as a "road map" framework to determine the value of options embedded in the M\&A deal. Therefore, the managerial synergies acquired from a merger can be valued as a real option (Čirjevskis 2021b).

Thus,

Proposition 2. A real options application to $M \mathcal{E} A$ deals is a strategic decision-making tool, being both a strategic observation "road-map" and the appropriate valuation technique of MEA-based synergies.

\subsection{Exploring of Real Options Value's Variables}

Real options originated from the Black-Scholes option-pricing model (BSOPM) coined to value financial options (Copeland and Keenan 1998a; Tong and Reuer 2007). Therefore, to understand the mechanics of real options, some analogies between real and financial options are traditionally drawn (Luehrman 1995; Mun 2002, pp. 99-102). A financial option itself is a right, but not an obligation to exercise either the right to buy (call option) or the right to sell (put option). European options are exercisable only at maturity, whereas American options - at any date before the option's expiration (Hull 2018).

Because the upside potential of an investment is theoretically unlimited, while the downside is limited to initial outlay (or fixed costs) associated with it, real options for the company are like long positions in financial markets. Conventionally, most expansion options are akin to long calls, whereas abandonment options and several switching options may be technically viewed as long puts (Mun 2002, p. 100; Damodaran 2012). Scholars (Luehrman 1998a; Vintila 2007) argued that an investment opportunity is identical to financial options as a firm has the right but not the obligation to make investment decisions as shown in Table 1. 
Table 1. The correspondence between financial options and real options.

\begin{tabular}{ccc}
\hline Financial Call Options & Variables & Real Options/Investment Opportunities \\
\hline Stock price & $\mathrm{S}$ & $\begin{array}{c}\text { The monetary benefits (present value of free cash } \\
\text { flows) to be received from the acquired project assets }\end{array}$ \\
\hline Exercise (strike) price & $\mathrm{X}$ & Costs required to acquire the project assets \\
\hline Time to expiration & $\mathrm{T}$ & Length of time the decision may be deferred \\
\hline Variance of stock returns & $\sigma^{2}$ & Riskiness of the asset \\
\hline Time value of money & $\mathrm{rf}$ & Risk-free rate of return \\
\hline Dividend yield & $\delta$ & Loss of value by deferring an investment decision \\
\hline Source: adapted from Luehrman (1998a) and Vintila (2007) and extended by the author.
\end{tabular}

Luehrman's (1995, 1998a, 1998b) writings on real options addressed investments in real assets as European options, wherein only a single real option-deferral, was considered. However, his approach has since been acknowledged as too simplistic and flawed (Borison 2005; Brandão et al. 2005). In reality, most real options resemble American-style options, albeit with a more complex structure (Mun 2002, p. 172). Since real options are real-world counterparts of the options found in financial markets, the value of a real option, in general, will also depend on similar factors (Mauboussin 1999; Bailey et al. 2003; Suto et al. 2008).

The underlying asset (or simply the "underlying") represents the monetary benefits (nominally FCF's) to be received over real option(s) duration without any exercises (Luehrman 1995; Mauboussin 1999; Damodaran 2005). The underlying traditionally is either net present value (NPV), as exemplified by Luehrman (1998a), if it is an investment initiative with fixed costs, or the company's discounted future free cash flow (i.e., PV). (Mun 2002, pp. 172, 175; Kodukula and Papudesu 2006, p. 85). The benefits gained by realizing an individual real option (denoted as $\mathrm{S}$ or $\mathrm{V}$ ) are either predetermined in advance or expressed as a fraction of the underlying value (Nembhard and Aktan 2009, pp. 25-31).

The "strike price" (X, K, or E) of a real option represents the (capital) expenditures or fixed costs associated with the implementation of the real option. For simple investment, deferral option costs of the real option is PV of the fixed costs, as initially discussed by Luehrman (1998a). In more complex, real options situations, however, contemporary analysts may also express real option costs as a function of the underlying [similarly to the benefits] (Mun 2003, p. 154).

Time to real option's expiration or maturity ( $t$ or $\mathrm{T}$ ) is the time frame in which real option may be exercised; longer periods will entail higher uncertainty and hence higher real option value (ROV) (Leslie and Michaels 2000). As noted by Li et al. (2007), real options maturity date is the deadline by which the company's management must decide. Either it is an arbitrary set or there is a need to change investment strategies. At the maturity, ROV reverts to zero; then the real option becomes worthless, as there is no flexibility left for the management (Mun 2002, p. 100). Time to maturity should not be mistaken with the length of time a real option is kept open, before either being realized or left to expire worthlessly - this time frame is referred to by Adner and Levinthal (2004) as the "holding period".

The time value of money is accounted for via the risk-free rate ( $\mathrm{rf}$ or $\mathrm{r}$ ), which is the systematic (market) risk that cannot be diversified as indicated by Mun $(2002, \mathrm{p}$. 60). The risk-free rate applied in the real options valuation process is the rate of return on riskless assets, whose maturity is equivalent to the maturity of the real option(s). A higher riskfree rate generally will entail a higher value of managerial flexibility. The conventionally risk-free rate is obtained from financial markets, representing the interest earned from government-issued financial security-e.g., bill or bond (Luehrman 1995; Stout et al. 2008; Nembhard and Aktan 2009, p. 25).

The risk that there may be fluctuations in the value of the underlying is expressed by the volatility factor $(\sigma)$, commonly measured by standard deviation. Derivation of "trustworthy" volatility measure for the underlying is one of the basic hindrances in the 
valuation of real options (Luehrman 1995; Kodukula and Papudesu 2006, pp. 89-93). Mun (2002, pp. 197-202) recounts the range of volatility estimation approaches proposed, which include logarithmic return approaches, financial modeling, (an educated) guesswork, historical data analysis, market data (proxy) analysis, and simulation. In the real options tradition, high volatility increases the value of an option to invest, delaying investment Dixit and Pindyck (1994), and adversely affecting the firm's economy.

Since a real option, as a financial option, is not an obligation, its value is never negative and the payoff from it can be expressed via the following relation (Mun 2002, p. 77): $R O V=S-X$, if and only if $S>X$, and $R O V=0$, if and only if $S \leq X$. Therefore, the real option value can be expressed via the following equation: ROV = MAX [S - X; 0]; where, $\mathrm{S}=$ benefits of the real option; $\mathrm{X}=$ costs of the real option. (Bailey et al. 2003). In this vein, any given real option, in parallel with financial options, may have three degrees of "moneyness" that measures how profitable it is to realize the option (Mun 2002, p. 113): if $S>X$, then the option is said to be "in-the-money"; if $S=X$, then the option is said to be "at-the-money"; if $S<X$, then the option is said to be "out-of-the-money".

Those real options, which have (relative to others) a very high degree of moneyness, are in the so-called "deep-in-the-money-zone" (van Putten and MacMillan 2004). As claimed by Mun (2003, p. 48), such real options are "no-brainers" and must be exercised firstly to optimally utilize the company's resources. Conversely, real options that have a significantly low degree of moneyness are "deep-out-of-the-money", or as van van Putten and MacMillan (2004) note "in the flee zone". Such real options are essentially worthless and should be discarded - they are highly unprofitable, and no amount of flexibility could reverse the situation (Mun 2003, p. 48).

Thus,

Proposition 3. The synergies in an MEA deal are long call real options "in the money" $(S>X)$ with a "holding period" equal to the time length of managerial anticipation when synergies would be fully realized.

\subsection{Valuating Bank Equity and Measuring MEA Deal Synergies with Real Options}

Damodaran (2009) argues that banks, as financial service firms, are best valued using equity valuation models, rather than enterprise valuation models, such as DFCF, since items, such as changes in capital expenditures, net working capital, and debt, are not clearly defined (Damodaran 2009, p. 1). To stretch the understanding of the option-pricing approach for bank equity valuation and M\&A-based synergy valuations, let us reflect on how a bank's equity could be adapted as a call option, an option that, hypothetically, never matures.

One of the most comprehensive explanations was given by oGiommarino et al. (1989) as follows. Bank equity can be interpreted as a call option on the bank's assets, where spot price (S) is the total value of the bank's assets, and the exercise price $(\mathrm{K})$ is the face value of total debt liabilities. At maturity of the outstanding debt, the owners of a commercial bank can either "repurchases" the bank from creditors by making the required interest payment and principal refunding (exercise a call option) or walk away from their liability and, thus, relinquish ownership of the bank to the creditors (not exercise an option). An important step of this approach is to estimate the weighted average duration of debt liabilities (Čirjevskis and Sorokins 2014).

Thereby, the bank's equity value is a value of call option. The real options theory recognizes that the value of future growth opportunity is derived from the bank's strategic flexibility, which must explicitly account for adaptability and competitive responsiveness (Smit and Trigeorgis 2006). In this vein, the real options application is feasible for usage in bank valuation since operations on both assets and liabilities are significant for the banking business nature. Moreover, having analyzed 15 mergers and acquisition deals in the European financial service with an application of real options, Dunis and Klein (2005, p. 8) argued that collaborative deal synergies can be valued of a real option, as follows. 
Because the partners have a right, but not an obligation, to merge or not, the call option on the collaborative deal can be executed by business partners only in the case if the option would be "in the money".

The option of potential merger benefits to the shareholders is a European call option on the market value of the merged company, with the expected future stand-alone market value defined as the exercise (or strike) price (E, K, or X) (Dunis and Klein 2005, p. 7). The stock price (So) equivalent for the real option is the sum of market values of equities of merging financial service firms. Data of market capitalization are usually available on https: / / www.reuters.com/ (assessed on 19 August 2021), google.com/finance (assessed on 19 August 2021), and other available sources. The volatility ( $\sigma)$ of a stock price is available on the V-Lab (2021) Volatility Analysis, or can be obtained by direct observation. Duration ( $\mathrm{T}$ ) getting synergy is managerial anticipation of when M\&A synergies would be fully realized, in terms of the number of years following the completion of the merger. Regarding the risk-free rate (rf), it is a long-term government bond yield (Dunis and Klein 2005) in the country of leading partners of collaborative strategy.

The exercise price $(E, K$, or $X)$ is the sum of the hypothetical future market value of equities of the merging banks without a merger. Usually, the hypothetical future market value of the partnership firms without a merger can be predicted with different EV-based valuations using multiples and/or with discounted free cash flow forecasts. However, bank valuation poses a challenge due to difficulties in defining both debt and reinvestment, strict regulatory constraints, and differences from the accounting rules for the rest of the market (Damodaran 2009). In this vein, the bank's equity valuation by the Black-Scholes option-pricing model would be an appropriate valuation method of the hypothetical future market value of equities for the merging banks without a merger, as recommended by Čirjevskis and Sorokins (2014). However, due to the absence of data on weighted average durations of debt liabilities of each branch of Luminor Bank, this method was not used in the current research. In this vein, the paper employed the "excess return model" following Damodaran's (2009) recommendations on the bank equity's valuation techniques.

According to Damodaran (2009), three alternatives can be employed to value a bank's equity: a dividend discount model, a cash flow to equity discount model, and an excess return model (Damodaran 2009). While many analysts view the first model as old-fashioned, for the second and especially third: an excess return model devotes analyst attention and is used in the current paper. Specifically, the future value of bank equity can be written as the sum of equity capital invested currently in the firm and the present value of excess returns that the bank expects to make in the future. In this vein, the usefulness of this model is to forecast not only how the bank will direct its future investments, but also the returns it will make on those investments (Damodaran 2009).

Therefore, the option of the potential M\&A deal benefits to the bank shareholders is a real call option on the market value added of the merging companies with the expected future stand-alone market value defined as the exercise price. In this vein, modeling the real option as a European and American call option with a stochastic exercise price is a reasonable tool to measure M\&A-based synergy. The call option value (long call) is a competence-based synergy of M\&A results that can be calculated using an Excel spreadsheet in the European and American types of options. The research has evidenced that the binomial option-pricing model makes the calculations visible and strategically flexible, so the results can be easily communicated with practitioners, whereas Black-Scholes option-pricing model gives higher accuracy of results, but they are not so convenient in terms of intuitive reasoning in valuing real options as the binominal option-pricing model (Čirjevskis 2021b).

Thus,

Proposition 4. The synergies in MEA deals can be measured with the binomial option-pricing model, getting the better strategic observation of market value added variations and the Black-Scholes option-pricing model getting higher-level accuracy of the valuation. 
To test the internal and external validity of the propositions, an explorative case study on the cross-border merger of the Luminor Bank establishment was analyzed and interpreted.

\section{Case Study of Luminor Group AB: Synergies Creation and Appropriation}

Luminor Group AB (or "Luminor") was founded in August 2017 in Sweden, based on the Baltic branch operations of Nordea Bank Abp (Finland) and DNB Bank ASA (Norway). Technically, first, DNB Baltic acquired Nordea Baltic, second, Luminor Group AB (Sweden) acquired DNB Baltic created Luminor Estonia, Luminor Latvia, and Luminor Lithuania; and, third, Luminor Estonia acquired stakes of Luminor Latvia and Lithuania. The merger was completed on 1 January, 2019 (Estonian Public Broadcasting 2019a). After the completion of the merger, the total shareholder equity of Luminor amounts to EUR 1.8 billion and it is capitalized at Common Equity Tier 1 (CET1) 18\%. Luminor has over EUR 15 billion in assets (Estonian Public Broadcasting 2019b). Originally, Nordea owned the bigger stake $(56.5 \%)$ and DNB owned a minor stake $(43.5 \%)$ of Luminor Group AB (Sweden) (Estonian Public Broadcasting 2019b). Thus, in the current research, Nordea was considered the leading partner of this cross-border merger.

In September 2018, it was announced that $60 \%$ of Luminor shares would be sold to the Blackstone Group-led consortium. Blackstone was to pay approximately EUR 1 billion for a $60 \%$ stake. The transaction was approved by the European Commission in January 2019 (Estonian Public Broadcasting 2019b), and completed in September 2019 (Public Broadcasting of Latvia 2019). Blackstone is one of the largest global investment-holding corporations. Blackstone is planning to remain the shareholder for four to seven years, after which, it most likely will exit by listing Luminor on several stock exchanges (Estonian Public Broadcasting 2019b).

Let us start with an exploration of this cross-border merger by analyzing five types of synergies, according to (Feldman and Hernandez 2021). Luminor implemented two enhancements in three-lateral relationships with business clients of Estonia, Latvia, and Lithuania emerged, attracting more Baltic corporate and individual customers (an internal synergy), and transacting more effectively with each of those customers, including insurance, pension funds, and other financial services, by offering better terms for both sides (a relational synergy) (Feldman and Hernandez 2021). Thus, this merger was a "splice" of three nodes (Luminor Estonia, Luminor Latvia, and Luminor Lithuania), in which the acquirer Luminor Estonia inherited the contractual ties of the two other Baltic branches (network synergies).

There are two kinds of changes that drive network synergies of Luminor: inheriting new ties that the Latvian and Lithuanian branches bring to the Luminor Estonia's preexisting network (additive), and eliminating redundant ties that the acquirer Luminor Estonia and Luminor Latvia and Luminor Lithuania had in common (subtractive) (Hernandez and Shaver 2019). It should be noted that network synergies have only partially been achieved because Luminor did not enhance stand-alone profitability for all partners. For example, the return on equity (ROE) of Luminor Latvia was only $3.1 \%$ in 2019 , and $2.0 \%$ in 2020 (Luminor 2020).

According to Feldman and Hernandez (2021), while synergism lies in cooperative external ties for both network and relational synergies, there is a difference in the levels of analyses of those synergies. Relational synergies of Luminor derives from individual direct ties to these corporates and individual client branches. Network synergies benefit the Luminor Estonia position in a network embracing indirect business ties of the merged Baltic branches (Feldman and Hernandez 2021). Having integrated the three Baltic branches, as a cohesive whole, the Luminor group had simplified the corporate structure, reducing different overlapped management bodies, leading to cost-effective management (non-market synergies). Finally, the market synergies were achieved only partially. Even though Luminor is better equipped to counter increasing competition in the region and capitalize on scale and scope, to become the main universal bank for more business partners in the Baltics, the Bank did not achieve a 
sustainable return on equity $(7.1 \%)$ in comparison with the merging branches' cost of equity (10.0\%); an analysis of those issues are provided below.

Moreover, the initial realization timing for network synergies and market power synergies may be elongated as Luminor integrates external relationships while reconfiguring internal personnel and processes to run those partnerships, which requires time in terms of the synergy lifecycle, as shown in Table 2. Luminor's antecedents of all five types of synergies are presented in Table 2, which illustrates economic reasons, explanations, and results.

Synergies provided by the cross-border merger can be measured by the real options application. Using option variables to value synergies, of an establishment of Luminor with BSOPM, as well as with recombining binomial lattices (underline the value and real option value) parameters of BOPM are further discussed in this paper. There are five input variables needed to apply Black-Scholes option-pricing model: the stock price (So); time to maturity $(\mathrm{T})$; volatility $(\sigma)$; risk-free rate (rf); and strike price $(\mathrm{K}, \mathrm{X}$ or $\mathrm{E})$. The stock price (So) equivalent for the real option is the sum of market values of equities of merging financial service firms. In this vein, the market value of the consolidated equities of DNB and Nordea branches in the Baltic States was EUR 1.714 million (Luminor 2017, p. 8). Duration (T) getting synergy is the managerial anticipation of when merger synergies are fully realized.

Previous studies on the periods of getting synergies in M\&A deals of stock-listed companies recommended using one-year duration ( $\mathrm{T}$ ) of achieving synergy (Dunis and Klein 2005, p. 7), three years after acquisition (Vergos 2003; Čirjevskis 2021c), or even up to 10 years (Damodaran 2002). Because the merger was completed on 1 January, 2019 (two years after the inception), the duration of getting synergy was taken like two years, which also corresponded with the deal of the Blackstone acquisition of Luminor in September 2019. This strategic milestone could be considered as the moment when Luminor expected to receive anticipated synergies.

Regarding the risk-free rate (rf), a long-term government bond yield (Dunis and Klein 2005) in the country of leading partners was used. By following the recommendation by Dunis and Klein (2005), the volatility of Nordea as a leading partner of the cross-border mergers was taken. The average risk-free rate in Finland was 1.7\% (Statista 2021a). Thus, the risk-free rate for Nordea was the average risk-free rate (rf) of investment in Finland in $2017-1.7 \%$ (Statista 2021a). The volatility $(\sigma)$ of a Nordea stock price within one week after the announcement of the merger was 31.47\% (V-Lab 2021).

A bit problematic was obtaining the exercise (or strike) price $(X, K$, or $E$ ) as the sum of the hypothetical future market value of equities of the merging banks without a merger. Usually, the hypothetical future market value of the partnership firms without mergers can be predicted with different EV-based valuations using multiples and/or with discounted free cash flow (DFCF) forecasts. However, bank valuations pose challenges due to difficulties in defining debt and reinvestment, strict regulatory constraints, off-balance items, and differences from the accounting rules for the rest of the market (Damodaran 2009).

In this vein, to measure hypothetical future market values of equities, of the merging banks without a merger, the paper employed Damodaran (2009) recommendations on the "excess return model" as a bank equity's valuation technique. When it comes to a bank's equity valuation with the Black-Scholes option-pricing model (Čirjevskis and Sorokins 2014), it did not apply to this research, as it is not able to define a weighted average duration of debt liabilities of each Baltic branch.

There are two inputs needed to value equity in the excess return model. The first is a measure of equity capital currently invested in the financial service firm. The equity capital currently invested in a bank is usually measured as the book value of equity in the bank (Damodaran 2009, p. 23). The excess returns, defined in equity terms, and could be stated in terms of the return on equity and the cost of equity, are as follows: excess equity return $=($ return on equity - cost of equity $) \times$ (equity capital invested $)$. This model considers not only where the financial service firm will direct its future investments, but also the returns it will make on those investments (Damodaran 2009, p. 23) 
Table 2. Exploration of antecedents of Luminor's synergies: Types, definitions, analyses, and results.

\begin{tabular}{|c|c|c|c|c|c|}
\hline $\begin{array}{l}\text { Type of } \\
\text { Synergies }\end{array}$ & Definition of Synergies & Luminor's Antecedents of Synergies & $\begin{array}{c}\text { Duration of Synergy } \\
\text { Gains }\end{array}$ & $\begin{array}{c}\text { Timing of } \\
\text { Initial } \\
\text { Synergy } \\
\text { Realization }\end{array}$ & Results \\
\hline $\begin{array}{l}\text { Internal } \\
\text { synergies }\end{array}$ & $\begin{array}{l}\text { Synergies are based on } \\
\text { tangible or intangible } \\
\text { resources and capabilities that } \\
\text { merging firms legally own } \\
\text { and control. }\end{array}$ & $\begin{array}{l}\text { By merging the three banking groups and } \\
\text { forming the branches, it helps to exploit } \\
\text { economies of scale and scope thanks to a } \\
\text { common organization across home and } \\
\text { host countries. Operational and funding } \\
\text { independence over time: IT separation } \\
\text { and consolidation, set-up of required } \\
\text { group functions and drive balance sheet } \\
\text { efficiencies. }\end{array}$ & $\begin{array}{l}\text { Long, requiring } \\
\text { continued investment }\end{array}$ & Medium & Achieved \\
\hline $\begin{array}{l}\text { Market } \\
\text { power } \\
\text { synergies }\end{array}$ & $\begin{array}{l}\text { Synergies are based on } \\
\text { 'horizontal' exchanges with } \\
\text { rivals that reduce the power } \\
\text { of counterparties and reduce } \\
\text { the costs of coordinating and } \\
\text { contracting activities that } \\
\text { might be higher than the costs } \\
\text { of internalizing them. }\end{array}$ & $\begin{array}{l}\text { The merged Baltic bank is better equipped } \\
\text { to counter increasing competition in the } \\
\text { region and capitalize on a scale to become } \\
\text { the main universal bank for more } \\
\text { businesses, customers, and partners in the } \\
\text { Baltics. The merger has a positive effect in } \\
\text { terms of compliance with capital } \\
\text { adequacy requirements. However, the } \\
\text { performance did not achieve a sustainable } \\
\text { return on equity in line with the } \\
\text { company's cost of equity. }\end{array}$ & $\begin{array}{l}\text { Long, if industry } \\
\text { forces remain in } \\
\text { equilibrium }\end{array}$ & Short & $\begin{array}{c}\text { Partly } \\
\text { achieved }\end{array}$ \\
\hline $\begin{array}{l}\text { Relational } \\
\text { synergies }\end{array}$ & $\begin{array}{l}\text { Synergies are based on } \\
\text { partner-specific assets, such } \\
\text { as mutual trust, governance } \\
\text { routines, contracting } \\
\text { capabilities, or } \\
\text { knowledge-exchange capacity. } \\
\text { The synergies allow all } \\
\text { parties to create and } \\
\text { appropriate more value. }\end{array}$ & $\begin{array}{l}\text { Creation of a leading customer-centric, } \\
\text { primary Baltic bank with Nordic roots: } \\
\text { achieve service excellence and implement } \\
\text { operational excellence. This is possible } \\
\text { because the preferences for various } \\
\text { financial services are similar across the } \\
\text { Baltic countries and the knowledge of } \\
\text { customers in one country implies } \\
\text { knowledge of customers in the other }\end{array}$ & $\begin{array}{l}\text { Medium, requiring } \\
\text { continued investment }\end{array}$ & $\begin{array}{l}\text { Medium to } \\
\text { long }\end{array}$ & Achieved \\
\hline $\begin{array}{l}\text { Network } \\
\text { synergies }\end{array}$ & $\begin{array}{l}\text { Synergies are based on } \\
\text { acquiring a target whose } \\
\text { alliance network, when } \\
\text { combined with that of the } \\
\text { acquirer, puts the combined } \\
\text { entity in an improved } \\
\text { structural position }\end{array}$ & $\begin{array}{l}\text { The combined Baltic banking business } \\
\text { benefits from clear strategic objectives, a } \\
\text { larger scale, and enhanced stand-alone } \\
\text { profitability with a dedicated } \\
\text { management team. Under these } \\
\text { conditions, there are also cost savings } \\
\text { from integrated accounting and } \\
\text { management information systems. }\end{array}$ & $\begin{array}{l}\text { Short, a structure can } \\
\text { change fast without } \\
\text { the bank's control }\end{array}$ & Immediate & $\begin{array}{c}\text { Partly } \\
\text { achieved }\end{array}$ \\
\hline $\begin{array}{l}\text { Non-Market } \\
\text { Synergies }\end{array}$ & $\begin{array}{l}\text { Synergies are based on } \\
\text { bringing multiple } \\
\text { stakeholders together and } \\
\text { provide an opportunity to } \\
\text { redefine the expectations and } \\
\text { rules of engagement with } \\
\text { those stakeholders }\end{array}$ & $\begin{array}{l}\text { By merging the three companies, the } \\
\text { Luminor group has a simpler corporate } \\
\text { structure. The number of different } \\
\text { management bodies was reduced, which } \\
\text { leads to more efficient and cost-effective } \\
\text { management, less bureaucracy, and a } \\
\text { strong corporate governance structure }\end{array}$ & $\begin{array}{l}\text { Medium, requiring } \\
\text { continued investment } \\
\text { in corporate } \\
\text { diplomacy and social } \\
\text { issue expertise }\end{array}$ & Very long & Achieved \\
\hline
\end{tabular}

Source: adopted from Feldman and Hernandez (2021) and extended by the author.

To value the Baltic branches of Nordea and DNB without the merger, the author begins with the current cost of equity, employing the CAPM model (Shapre 1990). According to Reuters (2021), DNB ASA Beta was 1.18 and Nordea Beta was 1.24 (Reuters 2021). Using the average beta 1.22 in 2017, in conjunction with an average risk premium $1.22 \%$ (Statista $2021 \mathrm{~b}$ ) and treasury bond rate of $1.7 \%$ (Statista 2021a), yields a cost of equity of $10 \%$ for their branches: cost of equity $=1.70 \%+1.22 \times 6.80 \%=10.00 \%$.

According to European Central Bank (ECB) data on ECB-directly supervised banks, the euro area bank average (ROE) equaled 6.0\% in 2017. (Latvijas Banka 2018). Concerning the overall performance indicator of all credit institutions of EU, annualized ROE calculated as profit/loss ratio to average capital and reserves of the reporting period (excluding data of foreign credit institution subsidiaries was 7.6\% in 2017 (Latvijas Banka 2018, p. 60)). While the return on equity at Baltic branches of DNB and Nordea was negative in 2016 (Luminor 2017, 2018), looking forward to the next 5 years, it was assumed that the expected return on equity (ROE) at DNB and Nordea bank branches (Luminor AB) would be $7.10 \%$, 
according to the CEO statement (Luminor 2018, p. 3). This also corresponds with an average ECB and analyst predictions.

The market value of the consolidated equities of DNB and Nordea branched was EUR 1.714 billion (Luminor 2017, p. 8) The resulting negative excess returns and present values are summarized in Table 3. Following the recommendations of Damodaran (2009, p. 24) on a 5-year duration forecast of excess return valuation, it was assumed that the net income would be perpetuity (Keown et al. 2005) at the level of the 2022 year and that the cost of equity, according to the capital asset pricing model (CAPM), would be unchanged $10.0 \%$.

Table 3. Excess return valuation-Luminor Group AB (in million).

\begin{tabular}{|c|c|c|c|c|c|c|}
\hline Items/Years & 2018 & 2019 & 2020 & 2021 & 2022 & $\begin{array}{l}2023 \text { and } \\
\text { Thereafter }\end{array}$ \\
\hline Net income & 122 & 130 & 140 & 149 & 160 & 171 \\
\hline Equity (EUR) & 1714 & 1836 & 1966 & 2106 & 2255 & 2415 \\
\hline Cost of equity (EUR) & 171 & 184 & 197 & 211 & 226 & 242 \\
\hline Excess equity return & $(49.71)$ & $(53.24)$ & $(57.01)$ & $(61.06)$ & $(65.40)$ & $(70.04)$ \\
\hline Present values interest factors (PVIF) & 0.9091 & 0.8264 & 0.7513 & 0.6830 & 0.6209 & \\
\hline Present value (PV) of excess equity return & $(45.19)$ & $(44.00)$ & $(42.84)$ & $(41.71)$ & $(40.61)$ & \\
\hline Beginning book value (BV) of equity & 1714 & 1836 & 1966 & 2106 & 2255 & \\
\hline Cost of equity $(\%)$ & $10.00 \%$ & $10.00 \%$ & $10.00 \%$ & $10.00 \%$ & $10.00 \%$ & \\
\hline Cost of equity (EUR) & 171 & 184 & 197 & 211 & 226 & \\
\hline Return on equity (ROE) \% & $7.01 \%$ & $7.01 \%$ & $7.01 \%$ & $7.01 \%$ & $7.01 \%$ & \\
\hline Net income & 122 & 130 & 140 & 149 & 160 & \\
\hline Dividend payout ratio & $0.00 \%$ & $0.00 \%$ & $0.00 \%$ & $0.00 \%$ & $0.00 \%$ & \\
\hline Retained earnings & 122 & 130 & 140 & 149 & 160 & \\
\hline Terminal value (TV) of excess equity return & & & & & & $(700.42)$ \\
\hline $\begin{array}{c}\text { Present value of the terminal value of excess } \\
\text { equity return }\end{array}$ & & & & & & $(434.90)$ \\
\hline Book value (BV) of equity invested currently & 1714 & & & & & \\
\hline $\begin{array}{c}\text { Present value of equity excess return (next five } \\
\text { years and TV) }\end{array}$ & $(649.24)$ & & & & & \\
\hline Theoretical market value of equity & 1064.76 & & & & & \\
\hline
\end{tabular}

Source: adopted from Damodaran (2009) and developed by the author.

When it comes to anticipated risks, banks usually have several off-balance sheet (OBS) items that relate to the risks incurred by a bank, dealing with non-traditional banking activities, such as financial derivative products (e.g., futures and options), guarantees, and letters of credit, which could affect the equity value in the future (Casu et al. 2006). "It is common to refer to the risks of these activities as OBS risks, but they nevertheless include all the main types of risk faced by banks including, credit risk, interest rate risk, exchange rate risk and liquidity risk" (Casu et al. 2006, p. 273).

According to the official data (Luminor 2017), Luminor AB takes on low exposure to market risk, which could be treated as the risk of losses in on- and off-balance sheet positions arising from adverse movements in market parameters, such as currency exchange rates (currency risk), interest rates (interest-rate risk), or equity prices (equity risk). The most significant part of market risk for a bank was interest rate risk, while the significance of other risks was lower (Luminor 2017, p. 34), which also justifies the chosen valuation method.

Therefore, the future theoretical market value of branch equities without merger $(X, K$, or E) equals EUR 1.07 billion. Thus, five input variables of the Black-Scholes option-pricing model (BSOPM) valuation are summarized in Table 4. The option premium as integrated synergy results was computed using an Excel spreadsheet. Results of cross-border merger synergies are presented in Tables 5-8, as follows. 
Table 4. Black-Scholes option-pricing model input variables.

\begin{tabular}{cc}
\hline Parameters & Data \\
\hline Stock price in million (So) & $1714 €$ \\
The strike price in million $(\mathrm{X})$ & $1065 €$ \\
The risk-free rate of return $(\mathrm{rf})$ & $1.70 \%$ \\
Time to expiration in years $(\mathrm{T})$ & 2.0 \\
The volatility $(\sigma)$ & $31.47 \%$ \\
\hline
\end{tabular}

Source: developed by the author.

Table 5. Black-Scholes option-pricing model's variables and results.

\begin{tabular}{|c|c|}
\hline \multicolumn{2}{|c|}{ Real Options Valuation: Black-Scholes Option-Pricing Model } \\
\hline $\begin{array}{l}\text { The cumulated market value of equity of Baltic branches of DNB and } \\
\qquad \text { Nordea (So) in EUR billion }\end{array}$ & 1.71 \\
\hline $\begin{array}{c}\text { Forecast of the hypothetical future market value of equities of Baltic } \\
\text { branches without merger }(X) \text { in EUR billion }\end{array}$ & 1.06 \\
\hline The risk-free rate of return (r) in 2017, Finland & $1.70 \%$ \\
\hline Time to expiration $(\mathrm{T})$ in years & 2.0 \\
\hline Volatility of share price $(\sigma)$ in 2017 after announcement, Nordea & $31.47 \%$ \\
\hline $\begin{array}{c}\mathrm{d} 1=((\ln (\text { So } / \mathrm{X})+\text { risk-free rate }+ \text { variance } / 2) \times \mathrm{T})) /[((\text { square root of } \\
\text { variance }) \times(\text { square root of } \mathrm{T}))\end{array}$ & 1.379 \\
\hline $\mathrm{d} 2=\mathrm{d} 1-($ square root of variance $) \times($ square root of $\mathrm{T})$ & 0.934 \\
\hline Value of the call option = Synergy $(C)$ in $€$ billion & 0.73 \\
\hline
\end{tabular}

Source: developed by the author.

Table 6. Binominal option-pricing model: a lattice of the underline values of Nordea and DNB Baltic branches merger (in $€$ billion).

\begin{tabular}{|c|c|c|c|c|c|}
\hline Stepping Time: $\delta$ t 0 & $\delta \mathrm{t} 1$ & $\delta \mathrm{t} 2$ & $\delta \mathrm{t} 3$ & $\delta \mathrm{t} 4$ & $\delta$ t 5 \\
\hline & & & & & EUR 4.64 \\
\hline & & & & EUR 3.80 & \\
\hline & & & EUR 3.11 & & EUR 3.11 \\
\hline & & EUR 2.55 & & EUR 2.55 & \\
\hline Underline value: & EUR 2.09 & & EUR 2.09 & & EUR 2.09 \\
\hline \multirow[t]{6}{*}{ EUR 1.71} & & EUR 1.71 & & EUR 1.71 & \\
\hline & EUR 1.40 & & EUR 1.40 & & EUR 1.40 \\
\hline & & EUR 1.15 & & EUR 1.15 & \\
\hline & & & EUR 0.94 & & EUR 0.94 \\
\hline & & & & EUR 0.77 & \\
\hline & & & & & EUR 0.63 \\
\hline
\end{tabular}

Source: developed by the author.

According to the Black-Scholes option-pricing model (BSOPM), the value of the real option (value of synergies) equals EUR 0.73 billion. The binominal option-pricing model (BOPM) equals EUR 0.62 billion. The difference in results of BSOPM and BOPM appeared due to relatively low numbers of time-step increments of BOPM. The shorter stepping time will result in higher granularity (more nodes) of the lattice. Lattices with higher granularity will provide more precise results, continually getting closer to the results of a BSOPM, if applicable (Kodukula and Papudesu 2006, p. 74). Mun (2002, pp. 153-54) noted that in the binomial lattice approach, some precision in determining ROV is inevitably lost; thus, with a small number of times steps, the main disadvantage of the binomial lattice approach 
becomes apparent. While Kodukula and Papudesu (2006, p. 96) indicate that in ROV, about four to six-time steps are commonly sufficient for good approximations.

Table 7. Recombining binomial lattice parameters.

\begin{tabular}{cc}
\hline Parameters & Data \\
\hline Time to expiration $(\mathrm{T})$ in years & $\mathrm{T}=2.0$ \\
\hline Number of steps $(\mathrm{N})$ & $\mathrm{N}=5.0$ \\
\hline Time increment (years) $(\delta \mathrm{t})$ & $\mathrm{T}$ \\
$\mathrm{N}$ & $=0.40$ \\
\hline Up factor $(\mathrm{u})$ & $\mathrm{u}=\mathrm{e}^{\sigma \sqrt{ } \mathrm{T}}=\frac{1}{\mathrm{~d}}=1.220$ \\
\hline Down factor $(\mathrm{d})$ & $\mathrm{d}=\frac{1}{\mathrm{u}}=0.820$ \\
\hline Risk-neutral probability $(\mathrm{p})$ & $\mathrm{p}=\frac{\mathrm{e}^{\mathrm{r} \Delta \mathrm{T}}-\mathrm{d}}{\mathrm{u}-\mathrm{d}}=0.467$ \\
\hline
\end{tabular}

Source: Developed by the author.

Table 8. Real options lattice: a value of synergies of Luminor merger (in $€$ billion).

\begin{tabular}{|c|c|c|c|c|c|}
\hline Stepping Time: $\delta$ t 0 & $\delta \mathbf{t} 1$ & $\delta \mathrm{t} 2$ & $\delta \mathrm{t} 3$ & $\delta t 4$ & $\delta \mathrm{t} 5$ \\
\hline & & & & & EUR 3.58 \\
\hline & & & & EUR 2.75 & \\
\hline & & & EUR 2.07 & & EUR 2.05 \\
\hline & & EUR 1.46 & & EUR 1.50 & \\
\hline Real option value: & EUR 0.97 & & EUR 0.95 & & EUR 1.03 \\
\hline \multirow[t]{5}{*}{ EUR 0.62} & & EUR 0.56 & & EUR 0.48 & \\
\hline & EUR 0.31 & & EUR 0.22 & & EUR 0.00 \\
\hline & & EUR 0.10 & & EUR 0.00 & \\
\hline & & & EUR 0.00 & & EUR 0.00 \\
\hline & & & & EUR 0.00 & \\
\hline
\end{tabular}

Source: developed by the author.

Even though BSOPM provides a quick and accurate real option result (Čirjevskis 2021a), BOPM provides a straightforward visualization of the uncertainty of a merger deal in terms of the volatility of underlying values (probable changes of value of the branches equities without the merger) and the volatility of the value of real options within the option's life cycle. According to BSOPM and BOPM, the real option was "in-themoney" and evidence that the DNB and Nordea had timely executed the long call option; thus, adding market value to shareholders of their banks, about EUR 0.70 billion by the establishment of Luminor Bank. These results justify the validity of propositions developed in the theoretical part of the paper. The application of the real options valuation to crossborder merger values synergy as market value added, not only as a cost-reducing/revenue increasing deal.

\section{Findings, Discussion, and Conclusions}

"Future research on synergy in M\&As should integrate all of the relevant literature streams. More specifically, scholars should analyze the connections among merging firm selection studies, synergy measurement models ... " (Fiorentino and Garzella 2015, p. 1492). The paper contributes to this scientific request by providing relevant synergy measurement models in M\&As, delivering a robust decision-making pattern to scholars, analysts, and practitioners to value cross-border merger synergies similar to the Luminor Group AB (Sweden) merger.

Contributions of the paper are threefold: real options theory, strategic management, and international business disciplines. Datta (1991) argued that most studies in strategic 
management have examined the M\&A performance as an implication of "strategic fit" or relatedness, whereas issues of "organizational fit" have received considerably less attention (Datta 1991, p. 281). The "strategic fit" concept suggests that the recombination of heterogeneous resources and their relatedness between buying and target firms, create synergy potential-a key determinant of value creation (Gomes et al. 2013).

However, failure to find a consistent relationship between synergy potential of strategic fit and merger and acquisition (M\&A) performance has led researchers to recognize that "organizational fit" between companies' in the post-deal (integration) phase might be the main determinant of overall M\&A performance (Weber and Fried 2011). Datta (1991) had defined "organization fit" as the extent to which the operations of the acquiring and acquired firms were integrated (Datta 1991). In this vein, Datta (1991) measured the impact of various activities in the post-deal phase on the acquisition performance and justified that other principal components of the integration process impacting the performance included marketing activity consolidation of, specifically, product markets served; distribution channels; promotion and advertising; and customer service (Datta 1991, pp. 287, 295).

Thereby, the paper contributes to strategic management by justifying that, even though "strategic fit" is an important antecedent of two well-known synergies, as internal synergies based on complementariness and compatibleness of resources and capabilities of merging partners (Čirjevskis 2021b), and market power synergies based on transferability of them (Čirjevskis 2015), with a long duration of the synergy gains, the analysis of the "operational fit" can unpack the three new types of synergies, with shorter (but important) synergy gains: relational, network, and non-market synergies.

Relational synergy can help achieve operational excellence in similar and related areas of activities of the merging partners by ensuring the exchange of knowledge, routines, and abilities across borders and, thus, appropriate more market value added. Network synergies help place partner entities into combined (and improved) structural positions, such as integrated management information systems, consolidated and integrated accounting, and unified reporting systems. Finally, non-market synergies, whose timing of a synergy realization is very long and requires investment in corporate diplomacy and expertise, could engage stakeholders in the creation of a more effective and strong corporate governance structure.

Thereby, the paper justifies Weber and Fried (2011) arguments that "organizational fit" between companies in the post-deal (integration) phase might be the main determinant of overall M\&A performance and, thus, synergies. Having explored and valued multiple types of synergies in the recent highly strategic cross-border merger of the Luminor Group AB, the paper reaffirms Feldman and Hernandez (2021) arguments that the value of mergers and acquisitions derives from the synergistic combination of an acquirer and a target.

The second contribution belongs to corporate finance. Ragozzino et al. (2016) argued that future empirical research on real options might focus on empirical contexts of merger and acquisition because internal and external opportunities are emerging in the integration phase. They are convinced that collaborative strategies context "represent ideal backdrops in which to study real options from a converging strategy and finance perspective ... These settings should become more central for future research in the area ... in which the valuation of opportunities is a crucial aspect of the strategic objectives pursued by firms". (Ragozzino et al. 2016, p. 21).

In this vein, the paper contributes to this request and demonstrates that the sum of values of different types of synergies in M\&A deals equals the market value added provided by the deal that could be valued with a real options application. An ROV application may serve as a decision-making tool and, at the same time, be a useful valuation method of M\&A deal synergies. The merger and acquisition can be exercised when the long calls real option is "in the money" $(S>X)$ with a "holding period" equaling the period of full synergy attainment. In this vein, the synergies of collaborative strategies can be measured by the combination of the Black-Scholes option-pricing model with the binomial option-pricing model, thus, providing highly accurate results of the valuation and clear 
strategic observation of the market value added variations, at the same time. Research demonstrates that the total market value added created by this cross-border merger can be valued as the sum of different types of synergies, with a real options application; thus, this paper provides a fresh empiric to the real options theory. This is the main contribution to corporate finance and real options theory.

Regarding the third contribution to the international business discipline, Buckley et al. (2017) argued that international business (IB) scholars "have much to offer in their ability to bring together the best approaches from multiple disciplinary and epistemological traditions, and to leverage this competitive advantage to build new theoretical insights" (Buckley et al. 2017, p. 1061). In their seminal paper on big questions and future research for IB scholars, Buckley et al. (2017) provided several important research topics. Among them, there is "the problem of increasing income inequality within and across countries and how multinational enterprises (MNEs) balance inequality within their network ... " (Buckley et al. 2017, p. 1060).

The paper contributes to the "grand challenges" (Buckley et al. 2017) research request, by exemplifying how multinational banks, Nordea (Finland) and DNB (Norway), have solved the problems of income inequality across their branches in the Baltic countries and balanced inequality of their performances within their network through a cross-border merger. Specifically, having done the case study on Luminor Bank, the international business strategies of two Scandinavian banks became obvious.

It was a strategic deal devoted to transforming the disparate and competing Baltic branches of Nordea and DNB, which also had problems with profitability (the ROEs at Baltic branches of DNB and Nordea were negative in 2016 before the merger; Luminor 2017, 2018) into a single integrated Baltic bank, Luminor, thereby maximizing the market value added due to the synergies provided by this merger transaction.

Eight months later, after the completion of the merger, in September 2019, Nordea and DNB sold $60 \%$ of the stake of Luminor to American investment fund Blackstone by keeping $20 \%$ each. That seems rational and a quite logical next strategic step is to monetize and appropriate the synergetic value of this transaction. Moreover, considering the "black swan" (Taleb 2007) COVID-19 pandemic, DNB and Nordea executed those international strategies, not only at "the right place", but the deal with Blackstone happened "at the right time", exactly before the start of the current pandemic. Therefore, this paper contributes to the international business discipline and provides fresh empirical research by demonstrating the solutions to the problem of income inequality of international corporations, within and across countries (Buckley et al. 2017, p. 1060).

However, intriguing new research questions have arisen, in regard to further examining the significance of the current findings, in light of the ongoing pandemic of COVID-19, and the latest legislation amendments in financial market law. "The ongoing coronavirus pandemic has created significant challenges for the banking sector across the EU ... The long-term effects of the covid-19 crisis on the EU banking sector cannot yet be quantified..." (Putnis et al. 2021, p. 1). Thereby, further research is needed to shed light on the legislative developments in the EU in the pandemic period, specifically to answer (i) how legislative instruments in the EU on financial market law could add value to the banking sector, in general; and (ii) what are the particular impacts of the COVID-19 pandemic, and the latest changes in the legislation on Luminor $A B$ business experiences after the acquisition of Blackstone?

\section{Limitations and Future Work}

Thus, the paper integrated synergy measurement models by answering the question "how" (Fiorentino and Garzella 2015) with the exploration of cross-border merger synergies, by answering questions "why" and "what" (Fiorentino and Garzella 2015). However, the current research did not unpack several synergy management pitfalls; particularly, it did not exactly answer "when" synergies show up and "where" and "why" dis-synergies could occur. There are several limitations of this research, as follows. 
Even though a synergy lifecycle, the timing of initial realization, and the duration of gains varying across the five types of synergies (Feldman and Hernandez 2021) were analyzed in Table 2, the paper did not explain why the market power and network synergies of Luminor's merger were only partially achieved. Whereas the duration of network synergy gain is short, and the time of network synergy realization is immediate, it can be concluded that Luminor neither effectively nor fully integrated the combined entities into an improved structural position (post-merger integration process issues).

In regard to market power synergies realization, with a long duration of the synergy gain and relatively short time of synergy realization-the partial achievement of this type of synergy (Table 2) might be related to insufficient capitalization, in scale and scope to become the big new Baltic universal bank and, thus, the cost reduction and revenue gains did not provide stakeholder satisfaction (the market size issues and competition). The promotion, advertising, or improved customer service (Datta 1991) left much to be desired. More research is needed to overcome the current limitations. Hence, it leads to several new propositions for future research.

First, more comprehensive future research can result from analyzing each synergy source separately based on differences of synergy lifecycles and timing of synergy gains in post-merger integration processes; thus, answering when and where each type of synergy shows up and how to value them separately from each other (Feldman and Hernandez 2021). Second, different synergies are likely measured through different indicators, and a single indicator of a merger's success will not seize the total value created (Zollo and Meier 2008). Feldman and Hernandez (2021) argue that value for different synergy types occurs over different time scales, and scholars may check it empirically.

To conclude, because of " ... unique configurations could arise within synergy types (e.g., originality of the combined internal assets), and across types (e.g., originality of the combined ... external networks, and stakeholder relations ... )" (Feldman and Hernandez 2021, p. 33), research should be conducted on many intriguing new hypotheses on appropriate synergy valuation models.

Funding: This research received no external funding.

Institutional Review Board Statement: Not applicable.

Acknowledgments: I gratefully acknowledge the assistance from Edmunds Badūns in the preparation of a key literature review on the real options theory.

Conflicts of Interest: The author declares no conflict of interest.

\section{References}

Adner, Ron, and Daniel A. Levinthal. 2004. What Is Not A Real Option: Considering Boundaries for the Application of Real Options to Business Strategy. The Academy of Management Review 29: 74. Available online: https://www.researchgate.net/publication/2284 03990 (accessed on 19 July 2021). [CrossRef]

Agaton, Casper Boongaling. 2021. Application of real options in carbon capture and storage literature: Valuation techniques and research hotspots. Science of the Total Environment 795: 148683. [CrossRef] [PubMed]

Agrawal, Ankur, Rajeev Varma, and Andy West. 2017. Making M\&A deal synergies count. McKinsey on Finance 64. Available online: https:/ / www.mckinsey.com/business-functions/strategy-and-corporate-finance/our-insights/making-m-and-a-dealsynergies-count (accessed on 19 July 2021).

Andrade, Gregor, Mark Mitchell, and Erik Stafford. 2001. New evidence and perspectives on mergers. Journal of Economic Perspectives 15: 103-20. [CrossRef]

Bailey, William, Benoît Couët, Ashish Bhandari, Soussan Faiz, Sundaram Srinivasan, and Helen Weeds. 2003. Unlocking the Value of Real Options. Oilfield Review 15: 4-19. Available online: https://www.researchgate.net/publication/287202550_ (accessed on 2 March 2021).

Barbopoulos, Leonidas G., Louis T. W. Cheng, Yi Cheng, and Andrew Marshall. 2019. The role of real options in the takeover premia in mergers and acquisitions. International Review of Economics \& Finance 61: 91-107.

Borison, Adam. 2005. Real Options Analysis: Where are the Emperor's Clothes? Journal of Applied Corporate Finance 17: 17-31. [CrossRef]

Brach, Marion. 2003. Real Options in Practice. Hoboken: John Wiley \& Sons, Inc. 
Brandão, Luiz E., James S. Dyer, and Warren J. Hahn. 2005. Using Binomial Decision Trees to Solve Real-Option Valuation Problems. Decision Analyses 2: 69-88. [CrossRef]

Buckley, Peter J., Jonathan P. Doh, and Mirko H. Benischke. 2017. Towards a renaissance in international business research? Big questions, grand challenges, and the future of IB scholarship. Journal of International Business Studies 48: 1045-64. [CrossRef]

Casu, Barbara, Claudia Girardone, and Girardone Philip Molyneux. 2006. Introduction to Banking. Harlow: Pearson Education Limited, vol. 10.

Chi, Tailan, Jing Li, Lenos G. Trigeorgis, and Andrianos E. Tsekrekos. 2019. Real options theory in international business. Journal of International Business Studies 50: 525-53. [CrossRef]

Čirjevskis, Andrejs, and Aleksandrs Sorokins. 2014. Valuing Strategic Flexibility with Black Scholes Option Pricing Model. Journal of Business Management 8: 25-34.

Čirjevskis, Andrejs. 2015. Empirical testing of the ARCTIC model for assessment of competence-based synergy in the acquisition process. Journal of Business Management 9: 63-73.

Čirjevskis, Andrejs. 2020. Do Synergies Pop Up Magically in Digital Transformation-Based Retail M\&A? Valuing Synergies with Real Options Application. Journal of Open Innovation: Technology, Market, and Complexity 6: 18.

Čirjevskis, Andrejs. 2021a. Value Maximizing Decisions in the Real Estate Market: Real Options Valuation Approach. Journal of Risk and Financial Management 14: 278. [CrossRef]

Čirjevskis, Andrejs. 2021b. Exploring the Link of Real Options Theory with Dynamic Capabilities Framework in Open Innovation-Type Merger and Acquisition Deals. Journal of Risk and Financial Management 14: 168. [CrossRef]

Čirjevskis, Andrejs. 2021c. Valuing Dynamic Capabilities-Based Synergies with Real Options. Journal of Risk and Financial Management 14: 69. [CrossRef]

Copeland, Thomas E., and Philip T. Keenan. 1998a. How much is Flexibility Worth? The McKinsey Quarterly 2: 38-49.

Copeland, Thomas E., and Philip T. Keenan. 1998b. Making real options real. The McKinsey Quarterly 3: 128-41.

Damodaran, Aswath. 2002. Investment Valuation: Tools and Techniques for Determining the Value of Any Asset, 2nd ed. Hoboken: John Wiley \& Sons.

Damodaran, Aswath. 2005. The Promise and Peril of Real Options. Available online: https://archive.nyu.edu/bitstream/2451/26802 /2/S-DRP-05-02.pdf (accessed on 19 July 2021).

Damodaran, Aswath. 2006. Valuation: Security Analysis for Investment and Corporate Finance, 2nd ed. Hoboken: John Wiley \& Sons, Inc.

Damodaran, Aswath. 2009. Valuing Financial Service Firms. Available online: http://people.stern.nyu.edu/adamodar/pdfiles/ papers / finfirm09.pdf (accessed on 20 July 2021).

Damodaran, Aswath. 2012. Investment Valuation: Tools and Techniques for Determining the Value of Any Asset. Hoboken: John Wiley \& Sons.

Datta, Deepak K. 1991. Organizational Fit and Acquisition Performance: Effects of Post-Acquisition Integration. Strategic Management Journal 12: 281-97. [CrossRef]

Dixit, Avinash K., and Robert S. Pindyck. 1994. Investment under Uncertainty. Princeton: Princeton University Press.

Dunis, Chrisitian, and Til Klein. 2005. Analyzing Mergers and Acquisitions in European Financial Services: An Application of Real Options. European Journal of Finance 11: 339-55. [CrossRef]

Estonian Public Broadcasting. 2019a. Luminor Merger Complete, Nothing to Change for Clients, Says the Bank. Available online: https:/ / news.err.ee/889123/luminor-merger-complete-nothing-to-change-for-clients-says-bank (accessed on 20 July 2021).

Estonian Public Broadcasting. 2019b. European Commission Clears Blackstone to Buy Luminor. Available online: https://news.err.ee/ 902757 / european-commission-clears-blackstone-to-buy-luminor (accessed on 20 July 2021).

Feldman, Emilie R., and Exequiel Hernandez. 2021. Synergy in Mergers and Acquisitions: Typology, Lifecycles, and Value. Academy of Management Review, 1-57. [CrossRef]

Ficery, Kristin, Tom Herd, and Bill Pursche. 2007. Where has all the synergy gone? The M\&A puzzle. Journal of Business Strategy 28: 29-35.

Fiorentino, Raffaele, and Stefano Garzella. 2015. Synergy management pitfalls in mergers and acquisitions. Management Decision 53: 1469-503. [CrossRef]

Giommarino, Ronald, Eduardo Schwartz, and Josef Zechner. 1989. Market Valuation of Bank Assets and Deposit Insurance in Canada. The Canadian Journal of Economics 22: 109-27. [CrossRef]

Gomes, Emanuel, Duncan N. Angwin, Weber Yaakov, and Shlomo Yedidia Tarba. 2013. Critical Success Factors through the Mergers and Acquisitions Process: Revealing Pre- and Post-M\&A Connections for Improved Performance. Thunderbird International Business Review 55: 13-35.

Goold, Michael, and Andrew Campbell. 1998. Desperately Seeking Synergy. Harvard Business Review 76: 130-43.

Helfat, Constance E., and Jeffrey A. Martin. 2014. Dynamic Managerial Capabilities: Review and Assessment of Managerial Impact on Strategic Change. Journal of Management 41: 1281-312. [CrossRef]

Hernandez, Exequiel, and J. Myles Shaver. 2019. Network Synergy. Administrative Science Quarterly 64: 171-202. [CrossRef]

Hoberg, Gerard, and Gordon Phillips. 2010. Product Market Synergies and Competition in Mergers and Acquisitions: A Text-Based Analysis. The Review of Financial Studies 23: 3773-811. [CrossRef]

Hull, John C. 2018. Options, Futures, and Other Derivatives, 10th ed. New York: Pearson Education. 
Keown, Arthur J., John D. Martin, William J. Petty, and David F. Scott. 2005. Financial Management: Principles and Applications, 10th ed. Hoboken: Pearson Prentice Hall.

Kodukula, Prasad, and Chandra Papudesu. 2006. Project Valuation Using Real Options: A Practitioner's Guide. Fort Lauderdale: Ross Publishing, Inc.

Kozlova, Mariia. 2017. Real option valuation in renewable energy literature: Research focus, trends, and design. Renewable and Sustainable Energy Reviews 80: 180-96. [CrossRef]

Latvijas Banka. 2018. Financial Stability Report. Available online: https://www.bank.lv/images/stories/pielikumi/publikacijas/FSR_ 2018_en.pdf (accessed on 16 August 2021).

Leslie, Keith, and Max Michaels. 2000. The Real Power of Real Options. McKinsey Quarterly. Available online: https://www. mckinsey.com/business-functions/strategy-and-corporate-finance/our-insights/the-real-power-of-real-options (accessed on 19 July 2021).

Li, Yong, Barclay E. James, Ravi Madhavan, and Joseph T. Mahoney. 2007. Real Options: Taking Stock and Looking Ahead. Advances in Strategic Management 24: 33-66.

Loukianova, Anna, Egor Nikulin, and Andrey Vedernikov. 2017. Valuing synergies in strategic mergers and acquisitions using the real options approach. Investment Management and Financial Innovations 14: 236-47. [CrossRef]

Luehrman, Timothy A. 1995. Capital Projects as Real Options: An Introduction. Harvard Business Review 9: 1-12. Available online: https:/ / www.hbs.edu/faculty/Pages/item.aspx?num=7577 (accessed on 19 July 2021).

Luehrman, Timothy A. 1998a. Investment Opportunities as Real Options: Getting Started on the Numbers. Harvard Business Review. Available online: https:/ /hbr.org/1998/07/investment-opportunities-as-real-options-getting-started-on-the-numbers (accessed on 19 July 2021).

Luehrman, Timothy A. 1998b. Strategy as a Portfolio of Real Options. Harvard Business Review 76: 89-101. Available online: https:/ /hbr.org/1998/09/strategy-as-a-portfolio-of-real-options (accessed on 19 July 2021).

Luminor. 2017. Luminor Group AB Consolidated Administration Report, Separate and Consolidated Financial Statements for the Year Ended 31 December 2017. Available online: https:/ / www.luminor.lv/sites/default/files/docs/finansu_parskati/luminor_ group_annual_report_2017.pdf (accessed on 20 July 2017).

Luminor. 2018. Luminor Bank AS Consolidated Annual Report Separate and Consolidated Financial Statement for the Year Ended 31 December 2018. Available online: https:/ / www.luminor.lv/sites/default/files/docs/finansu_parskati/luminor-lv-annualreport-2018-en.pdf (accessed on 20 July 2021).

Luminor. 2020. Luminor Holding AS Consolidated Financial Statements for the Year Ended 31 December 2020. Available online: https:/ / www.luminor.lv/sites/default/files/files/luminor_holding_as_annual_report_2020.pdf (accessed on 20 July 2021).

Martinsa, José, Rui Cunha Marques, and Carlos Oliveira Cruz. 2013. Real Options in Infrastructure: Revisiting the Literature. Journal of Infrastructure Systems 21. [CrossRef]

Mauboussin, Michael J. 1999. Get Real. Frontiers of Finance 10: 1-30.

Mun, Johnathan. 2002. Real Options Analysis, Tools and Techniques for Valuing Strategic Investments and Decisions. Hoboken: John Wiley and Sons.

Mun, Johnathan. 2003. Real Options Analysis Course's: Business Cases and Software Applications. Hoboken: John Wiley and Sons.

Nembhard, Harriet Black, and Mehmet Aktan. 2009. Real Options in Engineering, Design, Management, and Operations. Boca Raton: CRC Press.

Public Broadcasting of Latvia. 2019. blackstone closes $€ 1$ Billion Acquisition of Baltic bank Luminor. Available online: https: / / eng.lsm.lv/article/economy/banks/blackstone-closes-1-billion-acquisition-of-baltic-bank-luminor.a333643/ (accessed on 20 July 2021).

Puranam, Phanish, and Bart Vanneste. 2016. Corporate Strategy: Tools for Analysis and Decision-Making. Cambridge: Cambridge University Press, p. 288.

Putnis, Jan, Ben Goldstein, and David Kasal. 2021. The Banking Regulation Review: European Union. Law Review. Available online: https:/ / thelawreviews.co.uk/title/the-banking-regulation-review/european-union (accessed on 17 August 2021).

Ragozzino, Roberto, Jeffrey J. Reuer, and Lenos Trigeorgis. 2016. Real option in strategy and finance. Current Gaps and Future Linkages. Academy of Management Perspective 30: 428-40. [CrossRef]

Reuters. 2021. Available online: https: / / www.reuters.com/companies/NDAFI.HE/key-metrics (accessed on 20 July 2021 ).

Rhodes-Kropf, Matter, and David T. Robinson. 2008. The Market for Mergers and the Boundaries of the Firm. The Journal of Finance 63: 1169-211. [CrossRef]

Sakhartov, Arkadiy V., and Jeffrey J. Reuer. 2021. Is Synergy a Barrier to Business Exit? Strategic Management Review. Available online: https: / / leeds-faculty.colorado.edu/jere1232/smr.html (accessed on 19 July 2021).

Shapre, William. 1990. Capital Asset Prices with and without Negative Holding. Available online: https://www.nobelprize.org/ uploads /2018/06/sharpe-lecture.pdf (accessed on 20 July 2021).

Smit, Han, and Lenos Trigeorgis. 2006. Strategic planning: Valuing and managing portfolios of real options. RED Management 36: 403-19.

Statista. 2021a. Average Market Risk Premium (MRP) Used in Sweden from 2011 to 2021. Available online: https:/ /www.statista.com/ statistics /664819/average-market-risk-premium-sweden-europe/ (accessed on 20 July 2021). 
Statista. 2021b. Average Risk-Free Rate (RF) of Investment in Finland from 2015 to 2021. Available online: https://www.statista.com/ statistics / 885836/average-risk-free-rate-finland/ (accessed on 20 July 2021).

Stout, David E., Yan Alice Xie, and Howard Qi. 2008. Improving capital budgeting decisions with real options. Management Accounting Quarterly 9: 1-10.

Suto, Hirofumi, James Alleman, and Paul Rappoport. 2008. An Investment Criterion Incorporating Real Options. Communication and Strategies 70: 45-66.

Taleb, Nassim Nicholas. 2007. The Black Swan: The Impact of the Highly Improbable. The New York Times. Available online: https: / / www.nytimes.com/2007/04/22/books/chapters/0422-1st-tale.html (accessed on 20 July 2021).

Tong, Tony W., and Jeffrey J. Reuer. 2007. Real Options in Strategic Management. Advances in Strategic Management 24: 3-28.

Triantis, Alexander J., and Adam Borison. 2001. Real Options: State of the Practice. Journal of Applied Corporate Finance 14: 8-23. [CrossRef]

van Putten, Alexander B., and Ian MacMillan. 2004. Making Real Options Really Work. Harvard Business Review 82: 134-42. Available online: https:/ /hbr.org/2004/12/making-real-options-really-work (accessed on 19 July 2021).

Vergos, Konstantinos. 2003. Real Options and the Pricing of Shares. Ph.D. dissertation, University of Wales, Bangor, UK.

Vintila, Nicoleta. 2007. Real Options in Capital Budgeting. Pricing the Option to Delay and the Option to Abandon a Project. Theoretical and Applied Economics 7: 47-58.

V-Lab. 2021. Nordea Bank Abp GARCH Volatility Analysis. Available online: https://vlab.stern.nyu.edu/analysis/VOL.NDA\% 3AFH-R.GARCH (accessed on 20 July 2021).

Weber, Yaakov, and Yitzhak Fried. 2011. The role of HR practices in managing culture clash during the post-merger integration process. Human Resource Management 50: 565-70. [CrossRef]

$\mathrm{Yu}$, Jing, and Bin Xu. 2011. The game analyses to price the target enterprise of merger and acquisition based on the perspective of real options under stochastic surroundings. Economic Modelling 28: 1587-94. [CrossRef]

Zollo, Maurizio, and Degenhard Meier. 2008. What is M\&A performance? Academy of Management Perspectives 22: 55-77. 